\title{
Study on Water Assets Accounting under the Concept of Sustainable Development
}

\author{
Pingping Sun ${ }^{1,3}$, Hong Gan ${ }^{2,3}$, Ling $\mathrm{Jia}^{3}$, Changhai Qin ${ }^{3}$, Shuqian Wang ${ }^{1}$ \\ ${ }^{1}$ College of Water Conservancy and Hydropower, Hebei University of Engineering, China; \\ ${ }^{2}$ State Key Laboratory of Simulation and Regulation of Water Cycle in River Basin, \\ China Institute of Water Resources and Hydropower Research, China; \\ ${ }^{3}$ Department of Water Resources, China Institute of Water Resources and \\ Hydropower Research, China \\ aspingping0@163.com, bganhong@iwhr.com
}

\begin{abstract}
Keywords: water assets; water flow assets; water assets accounting; sustainable development Abstract. The economic accounting of natural resources assets, especially for water resources assets, is still in the exploratory stage in China. The contents and scope of water assets accounting need to be further improved. In order to explore the coordination between social and economic development and population, resources and environment, combined with the definition and attributes of assets in economics, accounting, statistics and management, this paper is based on the research about accounting of natural resources assets in recent years. The classification of water assets and its main accounting scope were put forward, and the intrinsic relationship between the concept of sustainable development and water accounting was systematically analyzed. The clear content of water assets is conducive to consolidating the construction of water assets accounting system, which can provide the theoretical basis for the decision makers to implement the sustainable development strategy, and to realize the rational allocation of water resources. It plays a catalytic role for the sustainable development of water resources and the protection of water ecological environment.
\end{abstract}

\section{Introduction}

With the development of society, the contradiction between supply and demand of water resources has become increasingly prominent, as well as the present situation of water resources shortage, serious pollution and uneven distribution of time and space in China. With the help of macroeconomic regulation and control of market economy, the optimal allocation of water resources under the reform of asset management system will greatly promote the sustainable use of water resources and sustainable development of social economy [1]. And the co-ordination between the sustainable development of social economy and population, resources, and environment, as one of the core concept of sustainable development, improves the rational allocation of resources and effective use. In recent years, the research on the capitalization management in natural resources especially in water resources is still in its infancy for China. In the process of accounting of natural resource assets, the economic development and water resources depletion, water environment damage are supposed to be balanced. On the other hand, the scope of water assets accounting is not yet clear, the relevant theoretical system needs to be improved.

\section{Accounting of Natural Resource Assets}

\section{Other natural resources assets}

SNA, as a set of conceptual and accounting frameworks that can effectively assess economic activities, has been revised five times since SNA-1953. And it has become a universal economic statistical standard system that provides effective economic analysis for decision makers. But due to human over concern about economic indicators for a long time, resources and environment have 
suffered an indelible damage. With the convening of the 1992 World Environment and Development Conference, the concept of "sustainable development" has become a new guiding ideology for countries to formulate economic development strategies. In 1993, the United Nations and the World Bank launched the first integrated System of Environmental Economic Accounting (SEEA) to assist the SNA. And the resources and environment impact from economic development was re-examined, which made important guiding significance for the sustainable development of global economy. SEEA-2012 is currently the most authoritative, seven major assets accounts are included, namely, mineral and energy resources, land, soil resources, timber resources, aquatic resources, other biological resources (timber resources and aquatic resources not included) and water resources.

In the international context of urgent reform in national economic accounting, a resource management concept of "harmonious development of human and nature" is advocated in China. A system of resources management suitable for Chinese national conditions is actively explored. It's an effective way to know the real situation of resources and monitor resource loss to carry out accounting research of natural resource assets. Since the 1980s, the price theory and property rights system on natural resources has been launched an academic discussion in Chinese scholars; At the beginning of the 21st century, accounting of natural resource assets were begun to practice with an opportunity of green GDP accounting; The heoretical research and practical use for accounting of natural resources assets were promoted once again by the balance sheet of natural resources assets mentioned on the Third Plenary Session of the 18th CPC Central Committee in China [2]. So far, pilots work have been carried out in the water resources, forest resources, energy resources, environmental pollution and mineral resources and some other areas in China [3]. Different accounting scope have been given in different resource attributes. To make forest resources as an example, forest resources accounting and system research on green economic evaluation were jointly carried out by the State Forestry Administration and the National Bureau of Statistics in 2013. Not only the trees, forests were respectively accounted by the way of stock and flow, but also the water conservation, conservation of soil, carbon sequestration and oxygen release, purification of atmospheric environment, forest protection, biodiversity conservation, forest recreation these seven categories of thirteen indicators were selected as the contents of forest ecosystem service values [4]; Another example for the mineral resources, those mined resources amount can be the accounting object mainly by its non-renewable, that is, the mineral resources reserves that can be developed and used under the current technical and economic conditions, and the reserves in the clear property rights on the basis by mining enterprises, reserved and available reserves are also included [5][6].

\section{Water resources assets}

In the traditional management of water resources, The inland renewable fresh water resources are carried out physical quantity accounting with some technical means like the development and utilization of evaluation, water resources bulletin preparation, etc in China. It's clear and helpful to understand the evolution of water resources and the use of the status quo, as well as its relationship with the economic society and the ecological environment [7]. With the economic development of water consumption depletion and water ecology deterioration, the traditional water resources management and accounting is not enough to evaluate the rationality of water use and coordination with economic development. The relationship of substance exchange can be reflected through the arrangement and integration of economic and environmental stock and flow information between the natural environmental resources and the economic society by SEEA. The System of Environmental Economic Accounting of Water (SEEAW) is based on water resources as the main accounting in order to achieve water conservancy statistics and national economic accounting docking. It can provide data support for water resource management and related decision-making, as well as provide a guarantee for the sustainable use of water resources through the water resources inventory and economic activities associated with the water supply and use accounting [8].

In recent years, international experience was fully learnt into China to explore the research on assets accounting account of water resources, and China System Environmental Economic 
Accounting of Water Research Report (CSEEAW2009) was completed in 2009 [9]. To explore the balance sheet of natural resources provided further support for water resources accounting in China. What's more, the relevant research work has been carring out by the National Bureau of Statistics, Ministry of Water Resources and other organizations. For instance, the water resources and changes table based on the physical water assets and assets accounts has been establishded, and the preparation of the accounts have been initially completed in numbers of pilot areas at present.

However, the water resources assets are mainly composed of those can be exploited and utilized in the past research. The accounting scope mainly includes surface water composed of reservoirs, lakes and rivers, shallow groundwater, etc [10]. But in fact, water resources affect the human life and production from the water quality, water quantity, water territory, water environment and some others. It creates resource conditions for the sustainable development of human society which can not be ignored. Therefore, it is necessary to determine a relatively complete accounting scope of the accounting system of water resources assets firstly, that is, the national (regional) and water rights entities should be considered based on the system analysis of general attributes.

\section{The concept and attributes of assets}

With the development of market economy, some neglected assets have been redefined. The connotation, diversification and general attributes of assets are systematically analyzed and summarized in this paper, which is based on the characteristics of economics, accounting, statistics and management.

The definition of assets in economics is a broad concept, that is a focus on the intrinsic economic value. It means future some economic benefits can be brought by these scarce resources [11],[12]. And the benefits and scarcity of assets can be emphasized from this definition [13],[14].

The definition of assets in accountings can be traced back to the beginning of the 20th century, and the concept of cost, future economic interests, rights, economic resources and liquidity, ect were included in the representative views [15]-[17]. The concept of future economic interests, as the main representative theory in 1985 , has been widely recognized by the accounting theory and countries which proposed by the United States Financial Accounting Standards Board (FASB) [18]. In 1989, the concept of the economic resources of assets was further raised by the International Accounting Standards Board (IASC) [19]. Based on the two views internationally accepted, Accounting Standards for Business Enterprises was revised in China in 2006. It thought that the assets of the enterprises was the past transactions or events formed, owned or controlled by them, which the future economic benefits were expected to be brought [20],[21]. In general, some basic features like already occurring, possessed or controlled, profitability and currency measurement are mainly emphasized by the accountings definition of assets.

The assets definition in Statistics can be embodied in the System of National Accounts (SNA-2008), which is published by five international organizations such as the United Nations, that is, a valuable reserves that represents the disposable or continuous economic benefits arising from the economic owner's entity hold or used over a period of time [22]-[25]. Thus, hold or used, profitability and valuable become the main features of statistical assets. However hold or used equates to the possessed or controlled in accountings.

Management believes that assets are economic resources that are directly or indirectly owned or controlled by firms that are formed by past events or transactions that create value for the customers [26],[27]. The benefits from the integration of internal resources and the rational allocation of resources are required by the main body of modern management [28]-[30]. Therefore, already occurring, ownership or controlled, profitability and valuable are the emphases in the management of the assets.

In summary, the one occurred for more than two times is selected as a general attribute of assets. Six attributes are totally referred in the various disciplines combined with the concept of various types 
of assets, namely Profitability, Ownership (possessed/controlled), Already Occurring, Valuable. As they are shown in Table 1.

Table 1 The comparison of asset attributes in each subjects

\begin{tabular}{ccccccc}
\hline Disciplines & Scarcity & Profitability & $\begin{array}{c}\text { Ownership } \\
\text { (possessed/controlled) }\end{array}$ & $\begin{array}{c}\text { Already } \\
\text { Occurring }\end{array}$ & Valuable & $\begin{array}{c}\text { Currency } \\
\text { Measurement }\end{array}$ \\
\hline Economics & $\mathbf{P}$ & $\mathbf{P}$ & $\mathbf{P}$ & $\mathbf{P}$ & $\mathbf{P}$ \\
Accounting & & $\mathbf{P}$ & $\mathbf{P}$ & $\mathbf{P}$ & $\mathbf{P}$ \\
statistics & & $\mathbf{P}$ & $\mathbf{P}$ & $\mathbf{P}$ \\
management & & $\mathbf{P}$ & $\mathbf{P}$ & $\mathbf{P}$ & \\
\hline
\end{tabular}

\section{Water assets and classification}

According to the above-mentioned summary of the asset attributes, water assets were divided into three types from the national assets management., including the water flow assets, water resources assets and hydro-ecosystem service values, but biological resources such as aquatic animals and plants were not included.

\section{Water flow assets}

The term water flow comes from Article 9 of the Constitution of China, namely mineral resources, water resources and other natural resources, all belong to the state. At the same time, water flow means rivers collectively that has important resource function and ecological function. The rights to water resources and other water ecological space like water territory and shoreline, etc are included in the work of water and property rights in China. According to this, water flow assets mentioned in paper, as a general term for water resources and water territory with assets attributes, is divided into water resources assets and water territory assets.

\section{( 1 ) National accounting}

Water resources assets Regarding the quantity of water resources as the corpus, water resources assets are considered as China's state-owned assets of natural resources [31]. The profitability is reflected from water resources which have created enormous economic benefits for human life and production [32]; The ownership attribute is embodied with the construction of property right system of water resources and the state-owned attributes in China; valuable attributes such as use value, labor value and compensation value are covered in water resources [33]; Combined with the current management status, the development of national economy is gradually restricted by water shortage and water quality deterioration. The scarcity of water resources is the main reason for the reform of management system and rational allocation of water resources. Therefore, they are necessary strategic assets of social development which are possessed with assets attributes. It is necessary to integrate all the water resources into assets management to meet water resources management requirements in China. Water resources assets refer to all inland resources that can or may be extracted for economic society. And the fresh and salt water should be included in it, so as to the renewable and can not be renewed water.

Water resources assets are further divided into exploited water resources assets and unexploited water resources assets according to the different features and different development utilization. The former refers to the requirements of the red line of water resources development and utilization can be met under the current economic and technological conditions in China. The inland renewable fresh water resources and brackish water resources that can be used are also included in that. According to the relevant provisions of China's three red line, exploited water resources assets (fresh water 
resources) should be up to 700 billion $\mathrm{m}^{3}$ in 2030 . Three kinds of water resources assets that can not be exploited are 1) those are not currently available for development and utilization, such as floods; 2) those have the development capability but not allowed to be developed or utilized from the management level, such as deep groundwater, basic ecological water, etc; 3) those have been destroyed and need to be repaired and repaid, such as pollution water resources.

Water territory assets These assets are derived from watershed resources, and water territory, shoreline (such as rivers, lake reservoirs and ports shoreline), etc are included in them. Water territory and shoreline, as a special natural resources and land resources, not only are provided with the natural properties like controling of flood, regulating of rivers' ecological balance, but also are possessed with the resources properties which provied the services of economic development and the value of resources utilization. They are the key to promote regional economy [34],[35]. In recent years, water territory and shoreline resources has become scarce gradually, as well as the frequent water pollution, shoreline occupation illegally and other issues in China. This situation is going to be solved in the recent development system of water flow rights through ensuring the territory and shoreline ownership. So territory and shoreline resources should be an indispensable part of national assets management [36],[37]. At present, the land of water resources and water conservancy facilities have been divided into the scope of land resources assets set by the National Bureau of Statistics, which lay the foundation for the accounting of water territory assets.

\section{( 2 ) Water entities accounting}

Water permission rights and water territory leasing rights are nonproductive assets derived from the water flow assets, which are derived from the use of the quantity or the territory of water resources by the water entities [38].

Water permission rights it's an important measure to solve the contradiction between supply and demand of water and to optimize the allocation of water resources [39], which is widely accepted in international water management [40]. The rights attribute of water permission is reflected through the way of how to determine the rights part of the water resources to the water users, which needs the application and auditing. The valuable attributes is related to the transference of water mentioned in the Water permission and Water Resources Fees Management Regulations that can provide the profit for water users. Therefore, these assets attributes are possessed in water permission rights. At present, the permission rights of natural resources represented by the water permission rights is also one of the assets of the SNA.

Water territory leasing rights it refers to a regular payment for owner that the tenants are allowed with the legal owners of water resources to use in return (called land rent, recorded as investment income) [24],[41]. After the lessee obtain the rights of using water territory, the territory can be cultivated or rental according to their own needs. The resources leasing requirements are satisfied by the way of renting water in SNA, so the water territory leasing rights is also an asset as a tradable operating lease.

\section{Other water assets}

Water engineering assets Water conservancy facilities (such as dams, embankments, hydropower stations, control gates, etc.), water supply facilities (such as Water supply and drainage equipment, sewage treatment devices, etc.), water monitoring and measurement facilities (such as hydrological instruments) and operation and management facilities of water conservancy engineering, etc are included in these fixed assets which are arising from the rational use of water resources [42]. Based on the analysis of investment and property rights system, the majority of water engineering assets are state-owned. A small number of water conservancy projects funded by collective or individual construction are devided to enterprises, collective or private assets. In accordance with the authority of management, it can be divided into central water engineering and local water engineering state-owned assets. Water engineering assets are the important components of fixed assets of water engineering system in China. 
Hydro-ecosystem service values Ecosystem goods is defined as some tangible material which is useful and valuable to humans by the processes and function of ecosystem in Resource Economics, ecosystem service is defined as useful and valuable improvements for humans in state or position [43]. In the field of water resources, the behavior of human beings from the ecosystem to obtain various water resources products is a typical aquatic ecosystem supply service, which is a typical tangible benefit; regulating water resources, purifying water quality and dealing with pollutants in water belong to hydro-ecosystem service, and it is also a typical intangible benefit [44]. In a broad sense, the water resources are owned by the state, and the same as to the whole people. So the hydro-ecosystem service derived from the waterresources can also be considered as state-owned. On the other hand, the study on water price theory provides the definition of the hydro-ecosystem service values. Therefore, hydro-ecosystem service values have the attributes of assets and can be regarded as intangible assets. However, there are few studies on the accounting of hydro-ecosystem services values, and how to integrate the system into the accounting system of water resources assets is worthy of further discussion.

\section{Sustainable Development Concept and Water Resources Accounting}

As the concept of sustainable development is widely accepted, the property attribute of water resources is gradually found by people. And water is not just resource, it is an asset, when it is operated into the market, not only will a loss or surplus brought to the users, but also to bring some impact to the national economy. As an integral part of accounting of natural resources assets, accounting of water resources assets is an important way for governments to understand the real water resources. It is more conducive to the rational allocation, the efficient development and utilization of water resources and the protection of water ecological environment. The above three goals are also the concrete manifestations of the concept of sustainable development. The realization of this goal means that water resources should be fully considered in the process of management and use of water resources and the coordination relationship among economic and social development and water resources and water environment.

Sustainable development concept and water assets accounting is complementary to each other, they both emphasize the balance between economic development and population, resources and environment through supplement and improvement of water resources accounting which aimed at water shortage, water environment deterioration and other aspects of the real problems. But the focus of them is different, sustainable development concept emphasizes the development of fairness, sustainability and environmental resources values, water resources accounting emphasizes the management of water resources and development status, is the implementation of the prerequisites for the concept of sustainable development. The relationship between water accounting and sustainable development concept is shown in Fig. 1. 


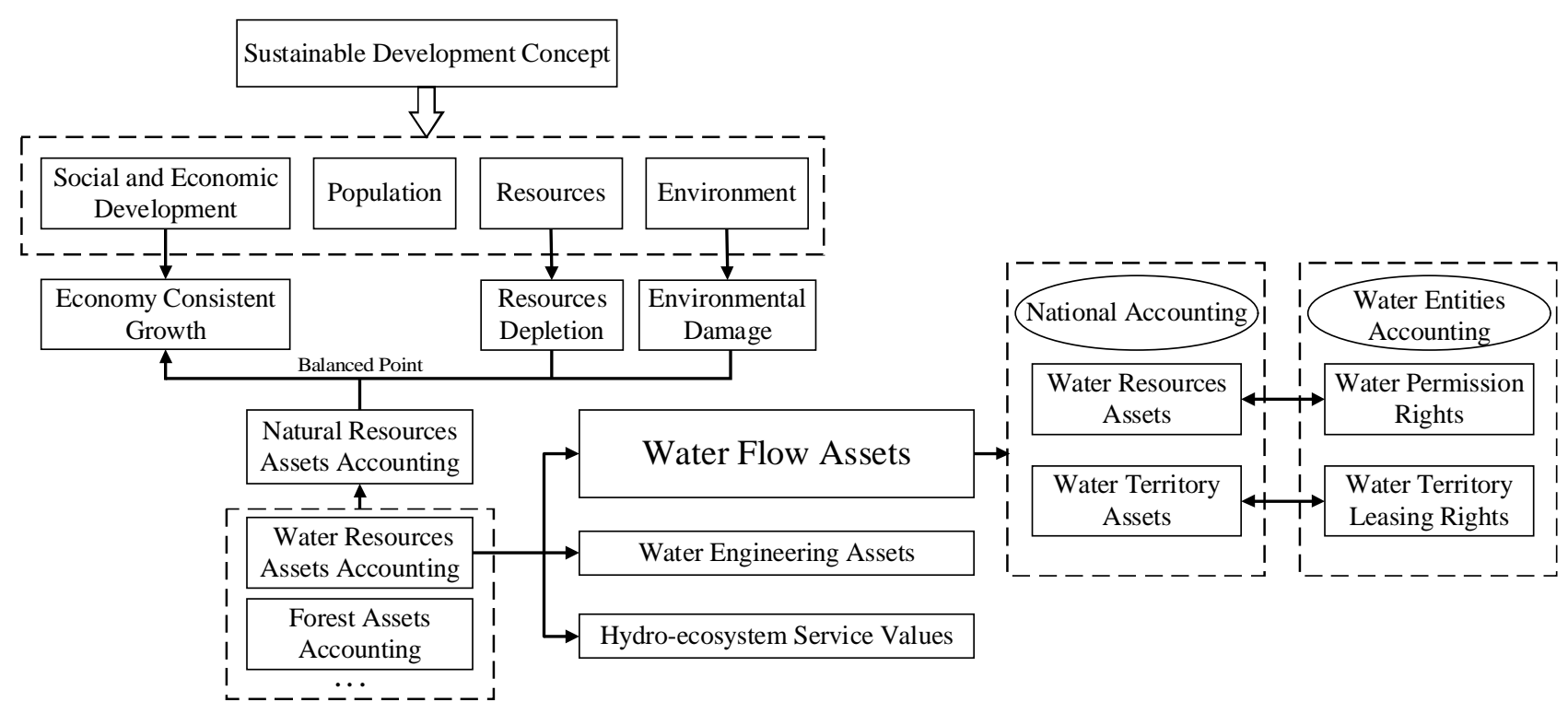

Fig. 1 The relationship between water accounting and sustainable development concept

\section{Conclusions}

Three categories water flow assets, water engineering assets and hydro-ecosystem service values mainly included in the water assets based on the general attributes of assets. It can be divided into water resources assets and water territory assets from the perspective of national accounting, and it can also be further divided into water permission rights and water territory leasing rights from the perspective of the main body of water rights. It is necessary to consolidate the accounting system of water resources assets. Some expansion ideas are provided for the following study of water resources assets accounting for the construction of water resources and property rights system in China.

As the basic theory of accounting, the relationship between the sustainable development concept and the accounting of water resources assets is discussed in this paper. And the definition and classification of water assets not only enriches the research contents of water assets accounting system, but also of great significance for comprehensive economic accounting; At the same time, the relevant research results provide management ideas for the sustainable use of water resources which can be used as an important decision basis of regional economic and social development strategy. The sustainable development concept is the guiding ideology of research on water assets accounting.

\section{Acknowledgements}

The researchers would like to extend their thanks to the Chinese National Natural Science Foundation (No.71573274, No.41401648, No.51279210) and the Chinese National Social Science Fund Project (No. 15ZDB160); The study was also supported by the Chinese Central Water Resources Fee Project—Construction of Water Right System and Pilot Project (No.126301001000150006).

\section{References}

[1] LI Lingyue, GAN Hong: Remark on the relationship between water resources rational allocation, carrying capacity and sustainable development (Advance in Water Science, China 2000).

[2] KONG H X, SHEN L, ZHONG S, et al: Research progress and controversial issues on natural resource accounting (Journal of Natural Resources, China 2016).

[3] FENG Z M, YANG Y Z and LI P: From natural resources accounting to balance-sheet of natural resources asset compilation (Ecosystem Service and Assessment, China 2014).

[4] In: China's forest resources accounting in the construction of ecological civilization system. Beijing (2015), in China Forestry Press. 
[5] Wang Guangcheng: The study of mineral resource valuation methods of the integerated accounting of natural resources and economy (Soft science, China 2001).

[6] Ling Jia, in: Research on the Issues of Environmental and Economic Accounting for Water Based on Computable General Equilibrium Model, Science Press (2012).

[7] In: Code of Practice for Water Resources Bulletin (GB/T 23598-2009), edited by General Administration of Quality Supervision, Inspection and Quarantine of the People's Republic of China, Standardization Administration of the People's Republic of China.,. Beijing (2009), in China Standard Press.

[8] GAN H, GAO M X: Basis and thoughts on creating the System of Environmental- Economic Accounting for Water (SEEAW) of China (China Water Resources, China 2008).

[9] In: Water Resources and Environmental Economic Accounting Research Report of China, edited by water resources and environment economic accounting research group, (2009), p. 121.

[10] WANG L, QIN C H, JIA L, et al: Interpretation of technical issues in physical asset account for water resources (China Water Resources, China 2016).

[11] Wang Z, Zhao B H, Yan A H: On the definition of assets (Journal Publishing Department of Agricultural University of Hebei, China 2002).

[12]Tang S L, Zhang Q F, in: Economics, Dalian (2016), in Dongbei University of Finance and Economics Press.

[13]Ge J S: The essence, definition and characteristics of the concept of assets (Economic Perspectives, China 2005).

[14] Chen G H, Sun Z M: The evolution and nature of the definition of asset (Friends of Accounting, China 2007).

[15]In: Subject Classification and Code of the People's Republic of China National Standards (GBT 13745-2009), Beijing (2009), in Standards Press of China.

[16] Cheng X Y, Ren Y C. A review of the research on the concept of assets in the joint project of the conceptual framework of IASB/FASB (Accounting Research, China 2010).

[17] Ge J S. Reflections on some basic concepts of financial accounting -- on the recognition and measurement of goodwill and derivative financial instruments (Communication of Finance and Accounting, China 2000).

[18]In: FASB. SFAC No. 6: Elements of Financial Statements, (1985).

[19]In: IASC. Framework for the Preparation and Presentation of Financial Statements, (1989).

[20]Niu X H, Li W D: Definition of Asset: Review and Reflect, (Communication of Finance and Accounting (Academic Edition), China 2007).

[21]In: Accounting Standards for Enterprises, edtied by Ministry of Finance, Beijing (2006), in Economic Science Press.

[22]Li W M, in: Financial Dictionary, Haerbin (2002), in Heilongjiang People's Press.

[23] Du J F, in: Basic Principles and Applications of National Economic Accounting, Beijing (2002), in China Financial Press.

[24]In: System of National Accounts-2008 (SNA-2008), edtied by the United Nations, the European Commission, et al., (2008).

[25]Li L Y, in: National economic accounting (Second Edition), Beijing (2014), in Tsinghua University Press.

[26] Wu Q, Dai W T, in: Management Science, Wuhan (2016), in Wuhan University Press.

[27]Liu J, Xu F, Dai Y, translate, in: Principles of Management (Second Edition), edtied by Mike Smith, Beijing (2015), Tinghua University Press.

[28] Gan S D, Wang S B: Assets: a comparative study of different subjects, (Reform of the Economic System, China 2000).

[29] Weng X C: Exploration on the management of fixed assets, (Co-operative Economy and Science, China 2010).

[30] Wu B, Yan X, Chen X W: Rethinking the distinction and connection between economics and management (Economic Review, China 2007). 
[31]LIU Y P, in: State-owned Assets Management (Third Edition). Beijing (2008), in Renmin University of China Press.

[32] WANG H, GAN H, WU B Q: Water resources assets and modern water. (China Water Resources, China 2002).

[33] GAN H, QIN C H, WANG L, et al: Study on water pricing method and practice I. Discussion on the connotation of water resources value (Journal of Hydraulic Engineering, China 2012).

[34]In: Dictionary of Maritime Law, edtied by SI Y Z, Beijing (1998), in China Communications Press.

[35] OU H Y. Preliminary study on assets management of shanghai port shoreline resources (Port construction, China 1999).

[36] XU M M: Research on the value of shoreline resources. (Science and Technology of Ports, China 2010).

[37]WANG J: Shanghai port shoreline resources and comprehensive utilization (Chinese Ports, China 2005).

[38] Gan Hong, Wang Lin and Qin Changhai, et al. Understanding of balance sheet of water resources (China Water, China 2014).

[39]LI W, SONG G J and YANG J R: Analysis on china's water abstraction license and abstraction charge policies (Water Resources Protection, China 2011).

[40]ZHENG F H, BI Z W and MENG F Y: Performance Evaluation on Implementation of Regulations Governing the Licensing for Water Drawing and the Levying for Water Resource Fees (Journal of South China Agricultural University (Social Science Edition), China 2010).

[41] Information on http://www.moa.gov.cn/sjzz/yzjzw/bjwj/201206/t20120613_2757139.htm.

[42]In: Classification and Codes for Fixed Assets (GB/T 14885-2010), edited by General Administration of Quality Supervision, Inspection and Quarantine of the People's Republic of China, Standardization Administration of the People's Republic of China. Beijing (2011), in China Standard Press.

[43]John C. Bergstrom, Alan Randall, in: Resource Economics Economic Analysis of Natural Resources and Environmental Policy, Beijing (2015), in Renmin University of China Press.

[44]In: Ecosystems and Human Well-Being. edtied by World Resources Institute. Beijing (2005), in China Environmental Science Press. 